GPJI 1 (2)(2017)
http://journal2.um.ac.id/index.php/gpi

\title{
PENGEMBANGAN PRODUK PERMAINAN MIKRO TENIS SEBAGAI ALTERNATIF KETERBATASAN KETERSEDIAAN FASILITAS LAPANGAN TENIS
}

\author{
Ricko Irawan $^{1,}$ Tri Nurharsono ${ }^{2}$, Agus Raharjo ${ }^{3}$ \\ Fakultas Ilmu Keolahragaan, Universitas Negeri Semarang
}

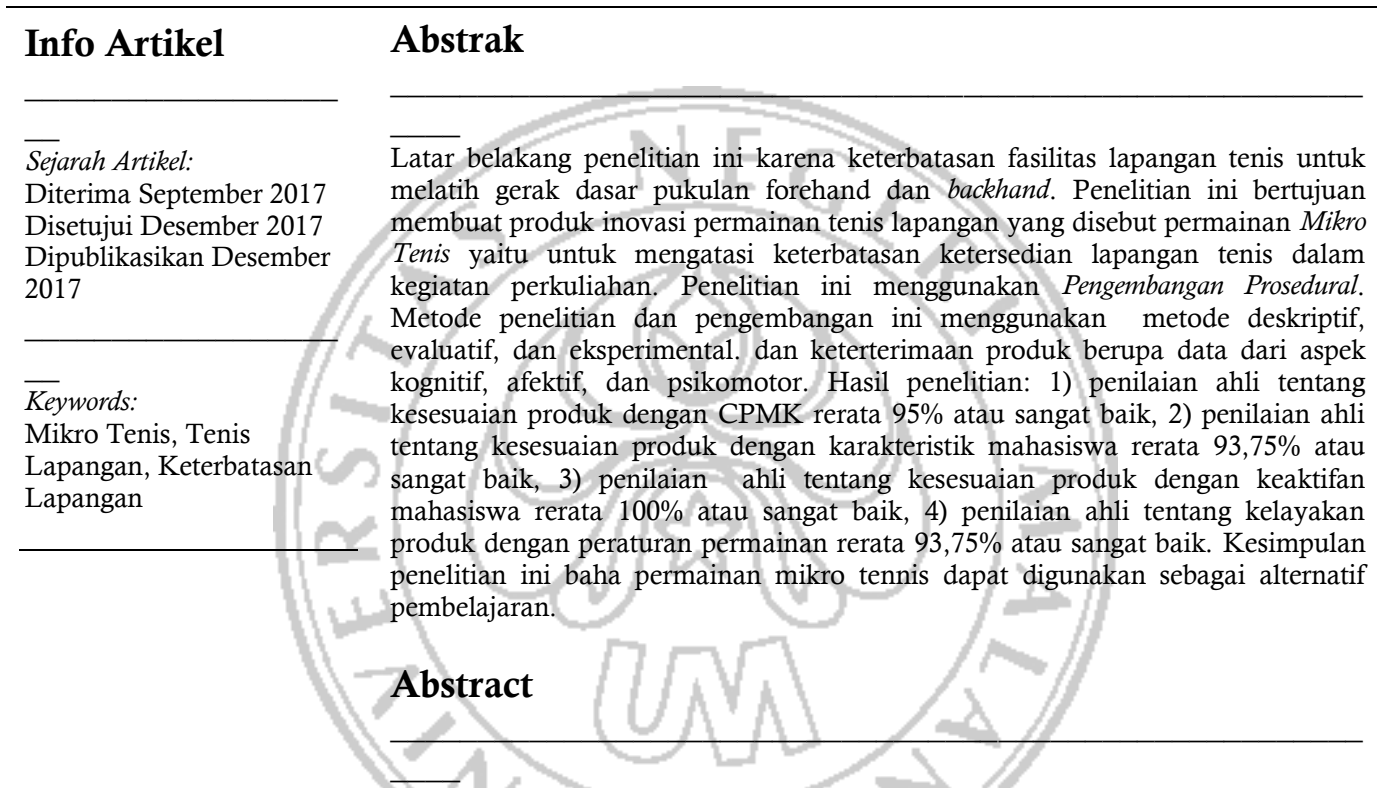

The background of this research is due to the limitations of tennis court facilities to train basic movements of forehand and backhand blows. This research aims to make innovation product of game tennis game called game of Mikro Tennis that is to overcome the limitations of tennis court availability in lecturing activity. This research uses Procedural Development. This research and development method using descriptive, evaluative, and experimental methods. and acceptance of products in the form of data from cognitive, affective, and psychomotor aspects. Result of research: 1) expert assessment about product conformity with CPMK average $95 \%$ or very good, 2) expert assessment about product suitability with student characteristic average $93,75 \%$ or very good, 3) expert assessment about product suitability with student activity average $100 \%$ or excellent, 4) expert judgment about product feasibility with average game rules of $93.75 \%$ or excellent.

(C) 2017 Universitas Negeri Malang

\footnotetext{
Alamat korespondensi:

E-mail: rickoirawan33@gmail.com
}

ISSN 0853-5043 (cetak)

\section{PENDAHULUAN}

Olahraga tenis lapangan, utamanya pada petenis tingkat dasar atau pemula dibutuhkan latihan normal minimal 3 kali dalam seminggu. Dalam satu pertemuan latihan berkisar antara 1,5 - 2 jam sehingga keterampilan petenis akan mengalami 
peningkatan. Karena pada dasarnya prinsip latihan adalah semakin sering kita melaksanakan latihan, maka semakin cepat pula keterampilan motorik seseorang akan terbentuk.

Mahasiswa PJKR FIK Unnes pada semester 4 mendapatkan mata kuliah tenis lapangan sebanyak 2 SKS, setiap SKS terdiri dari 170 menit, jadi total dalam satu pertemuan setiap kelas akan mendaptkan 340 menit. Akan tetapi dalam RPS dijelaskan bahwa 340 menit terdiri dari perkuliahan selama 100 menit dan 240 menit adalah tugas mandiri dan struktur. Artinya dosen harus memberikan tugas terstruktur atau mandiri diluar jam perkuliahan.

Dalam mata kuliah tenis lapangan salah satu indikator capaian pembelajaran mata kuliah adalah mahasiswa luwes dalam melakukan teknik pukulan forehand dan backhand. Oleh karena itu agar mahasiswa bisa melakukan teknik pukulan forehand dan backhand dengan luwes, maka dibutuhkan latihan yang intens dan terprogram.

Dosen selaku pengampu mata kuliah tenis lapangan menyadari bahwa, fakta di lapangan jika hanya mengandalkan pertemuan saat perkuliahan dengan waktu 100 menit dengan jumlah mahasiswa 30-35 orang, tentunya sangat tidak efektif untuk meningkatkan kualitas keterampilan mahasiswa, apalagi pada tahapan luwes. Oleh karenanya dosen pengampu sesuai dengan RPS harus mengoptimalkan jam diluar perkuliahan atau tugas mandiri yaitu 3 kali dalam seminggu. Akan tetapi yang menjadi kendala dalam penugasan mandiri atau terstruktur yang akan dilaksanakan oleh mahasiswa adalah keterbatasan ketersediaan lapangan tenis. Berdasarkan observasi dan wawancara tim peneliti di lapangan diperoleh fakta dan informasi bahwa terdapat keterbatasan sarana dan prasarana tenis lapangan yang disebabkan oleh jadwal pemakaian lapangan yang cukup padat.

Melihat fakta di atas jelas bahwa ketersediaan tempat atau lapangan tenis di FIK Unnes sudah sangat minim dan terbatas karena jadwal penggunaan lapangan sudah sangat padat. Berdasarkan permasalahan diatas kami tim peneliti berinisiatif menciptakan produk sebagai solusi alternatif terkait keterbatasan ketersediaan lapangan tenis di FIK Unnes dengan pengembangan model permainan Mikro Tenis. Sehingga produk permainan Mikro Tenis nantinya dapat digunakan tidak hanya di lapangan tenis, tetapi di lahan lain atau lahan terbuka. Akan tetapi fungsinya sama yaitu melatih keterampilan teknik dasar pukulan tenis.

Tenis merupakan cabang olah raga permainan yang tergolong dalam kelompok permainan bola kecil. Dalam permainan tenis masalah lapangan dan perlengkapan lain merupakan kebutuhan primer. Dalam pertandingan resmi dibagi dalam 3 (tiga) permukaan yaitu (1) Jenis permukaan rumput (Grass Court), (2) jenis permukaan keras (Hard Court), (3) jenis permukaan tanah liat (Gravel).

Kemudian dalam segi bangunan dibagi dalam 2 (dua) situasi lapangan dengan situasi terbuka (out door) dan lapangan dengan situasi tertutup (in door). Lapangan Tenis diantaranya dapat digunakan untuk rekreasi/olahraga rekreasi kesehatan, dan pembinaan prestasi, turnamen Amatir dan Profesional, dan untuk pembelajaran atau perkuliahan

\section{Permainan Mikro Tenis}

Olahraga merupakan suatu aktivitas jasmani yang dilakukan dengan gerak motorik sesuai dengan spesifikasi keterampilannya. Permainan menjadi salah satu kebutuhan hidup manusia untuk meningkatkan nilai kesegaran jiwa dan raga menjadikan suatu kesenangan dalam kegiatan diwaktu luang (rekreasi).

Permainan dalam olahraga dapat dikategorikan dalam 2 bagian, yaitu: menggunakan bantuan alat dan tidak menggunakan bantuan alat, contohnya olahraga permainan Tonnis, Tonnis meru-pakan olahraga yang menggunakan bantuan alat yaitu papan pantul yang disebut paddle, dimainkan di lapangan permukaan datar, gerak dasarnya seperti Tennis Lapangan, dapat dimainkan tunggal dan ganda. Pengembangan latihan mandiri tenis dapat dilakukan dengan bermain Mikro Tenis. Perlengkapan yang digunakan yaitu menggunakan bola Tenis/ Tonnis deberi tali karet panjang 3-4 Meter sesuai dengan penggunaannya dan diikatkan dengan batu alat pemukulnya adalah raket tenis. Permukaan lapangan datar (dapat dimainkan di tanah liat padat rata, paving, beton, aspal). Ukuran lapangan (lebar $4 \mathrm{~m}$ dan panjang $8 \mathrm{~m}$ )

Mikro Tenis adalah olahraga permainan dengan menggunakan perleng-kapan alat pemukul ( raket tenis/paddle tonnis ) dan bola Tennis/Tonnis diberi karet yang 
diikatkan pada pembeban/ batu, gerak dasarnya seperti bermain tenis hanya bola harus jatuh mantul terlebih dahulu baru dipukul (tidak boleh dipukul langsung/ di voli). Mikro Tenis mempunyai filosofi Mudah, Murah, Meriah dan Menyehatkan.

Cara bermain Mikro tennis adalah

1. Bola dipukul memantul pada area yang sudah ditentukan

2. Dapat dimainkan tunggal dan ganda

3. Bola setelah mantul di daerah sasaran kemudian dipukul oleh pemain dengan waktu yang sudah ditentukan oleh pemain itu sendiri

4. Jika permainan ganda, maka bola dipukul bergantian dengan pasangan.

5. Dapat dipukul forehand maupun backhand

\section{Karakteristik Mahasiswa}

Menurut Susantoro (1990:23) mahasiswa merupakan kalangan muda yang berumur antara 19 sampai 28 tahun yang memang dalam usia tersebut mengalami suatu peralihan dari tahap remaja ke tahap dewasa. Menurut Kamus Besar Bahasa Indonesia, mahasiswa adalah mereka yang sedang belajar di perguruan tinggi (Poerwadarminta, 2005: 375). Mahasiswa dapat didefinisikan sebagai individu yang sedang menuntut ilmu ditingkat perguruan tinggi, baik negeri maupun swasta atau lembaga lain yang setingkat dengan perguruan tinggi.

Mahasiswa dinilai memiliki tingkat intelektualitas yang tinggi, kecerdasan dalam berpikir dan kerencanaan dalam bertindak. Berpikir kritis dan bertindak dengan cepat dan tepat merupakan sifat yang cenderung melekat pada diri setiap mahasiswa, yang merupakan prinsip yang saling melengkapi. Mahasiswa adalah manusia yang tercipta untuk selalu berpikir yang saling melengkapi (Siswoyo, 2007:121). Mahasiswa adalah orang yang belajar di perguruan tinggi, baik di universitas, institut atau akademi, mereka yang terdaftar sebagai murid di perguruan tinggi. Karakteristik mahasiswa secara umum yaitu stabilitas dalam kepribadian yang mulai meningkat, karena berkurangnya gejolak-gejolak yang ada didalam perasaan. Mereka cenderung memantapkan dan berpikir 910 dengan matang terhadap sesuatu yang akan diraihnya, sehingga mereka memiliki pandangan yang realistik tentang diri sendiri dan lingkungannya.
Para mahasiswa akan cenderung lebih dekat dengan teman sebaya untuk saling bertukar pikiran dan saling memberikan dukungan, karena dapat kita ketahui bahwa sebagian besar mahasiswa berada jauh dari orang tua maupun keluarga. Karakteristik mahasiswa yang paling menonjol adalah mereka mandiri, dan memiliki prakiraan di masa depan, baik dalam hal karir maupun hubungan percintaan. Mereka akan memperdalam keahlian dibidangnya masing-masing untuk mempersiapkan diri menghadapi dunia kerja yang membutuhkan mental tinggi. Sedangkan karakteristik mahasiswa yang mengikuti perkuliahan tenis lapangan adalah memiliki rasa ingin tahu terhadap kemajuan tenis lapangan. Mereka cenderung untuk mencari bahkan membuat inovasi-inovasi terbaru di bidang olahraga tenis lapangan. Mahasiswa menjadi mudah terpengaruh dengan sesuatu yang baru, misalnya produk permainan.

Model pengembangan permainan foot and hand coordination merupakan salah satu solusi pemecahan masalah agar mahasiswa tidak merasa bosan, dan tidak kesulitan dalam melakukan permainan tenis lapangan khususnya permainan sepakbola dan bolabasket, (Farida, 2014). Pengembangan Bola Multifungsi untuk Pembelajaran Pendidikan Jasmani, Olahraga, dan Kesehatan merupakan model pengembangan permainan bola multifungsi untuk per-mainan bola voli, bola basket dan/sepak bola (Hartono, 2017).

Pengembangan permainan tonnis merupakan produk permainan modifikasi badminton dan tenis. Dimana raket yang digunakan menggunakan paddle, bola menggunakan bola gembos dan lapangan menggunakan ukuran lapangan badminton dengan ukuran net yang sudah dimodifikasi (Nurharsono, 2009).

Dalam produk mikro tenis yang dikembangkan peneliti, peneliti berusaha menciptakan suatu produk permainan sebagai solusi apabila terjadi keterbatasan lapangan tenis untuk perkuliahan atau kegiatan mandiri mahasiswa. Produk mikro tenis yaitu produk atau permainan dengan menggunakan perlengkapan alat pemukul (raket tenis) dan bola tennis/tonnis diberi karet yang diikatkan pada pembeban/batu, gerak dasarnya seperti bermain tenis, hanya bola harus jatuh mantul terlebih dahulu baru dipukul (tidak boleh dipukul langsung/ di voli). Mikro tenis mempunyai filosofi mudah, murah, meriah dan menyehatkan. 
Melihat fakta di atas jelas bahwa ketersediaan lahan lapangan tenis di FIK Unnes sangat terbatas karena jadwal penggunaan lapangan sudah sangat padat, sehingga mahasiswa kesulitan untuk melaksanakan proses latihan. Berdasarkan permasalahan diatas kami tim peneliti berinisiatif menciptakan produk sebagai solusi alternatif terkait keterbatasan ketersediaan lapangan tenis di FIK Unnes dengan pengembangan model permainan Mikro Tenis. Sehingga produk permainan Mikro Tenis nantinya dapat digunakan tidak hanya di lapangan tenis, tetapi di lahan lain atau lahan terbuka. Akan tetapi fungsinya sama yaitu melatih keterampilan teknik dasar pukulan tenis

Berdasarkan permasalahan diatas kami tim peneliti berinisiatif menciptakan produk sebagai solusi alternatif terkait keterbatasan ketersediaan lapangan tenis di FIK Unnes dengan pengembangan model permainan Mikro Tenis. Sehingga produk permainan Mikro Tenis nantinya dapat digunakan tidak hanya di lapangan tenis, tetapi di lahan lain atau lahan terbuka. Akan tetapi fungsinya sama yaitu melatih keterampilan teknik dasar pukulan tenis.

Tujuan penelitian ini dilakukan adalah untuk mempermudah mahasiswa melatih keterampilan pukulan forehand dan backhand dengan memaksimalkan lahan yang kosong, dengan demikian mahasiswa tidak hanya mengandalkan ketersediaan lapangan tenis saja. Sehingga diharapkan produk ini menjadi solusi alternatif bagi keterbatasan ketersediaan lapangan tenis di Universitas Negeri Semarang pada khususnya dan di Universitas lain pada umumnya.

\section{METODE}

Penelitian ini menggunakan Pengembangan Prosedural. Metode penelitian dan pengembangan ini menggunakan metode deskriptif, evaluatif, dan eksperimental. Prosedur yang digunakan dalam permainan mikro tenis, mencakup: (1) melakukan analisis produk yang akan dikembangkan (2) mengembangkan produk awal permainan Mikro Tenis (3) validasi ahli (4) uji coba produk, dan (5) revisi produk. Teknik analisis data yang digunakan adalah persentase untuk menganalisis dan penilaian subjek pengembang dalam menilai tingkat kelayakan, kualitas, dan keterterimaan produk berupa data dari aspek kognitif, afektif, dan psikomotor.

Teknik analisis data yang digunakan adalah prosentase untuk menganalisis dan penilaian ahli dalam menilai tingkat kualitas produk terhadap produk permainan. Hasil persentase yang diperoleh kemudian diklasifikasikan untuk memperoleh kesimpulan data. Pada tabel 1 akan disajikan klasifikasi persentase.

Tabel 1. Klasifikasi Prosentase

\begin{tabular}{ccc} 
Persentase & Klasifikasi & Makna \\
\hline $0-20 \%$ & Tidak baik & Dibuang \\
$20,1-40 \%$ & Kurang baik & $\begin{array}{l}\text { Diperbaiki } \\
\text { Digunakan } \\
\text { (bersyarat) }\end{array}$ \\
$70,1-70 \%$ & Cukup baik & Digunakan \\
$90,1-100 \%$ & Baik & Digunakan \\
\hline
\end{tabular}

Wahyudi, (2008)

\section{HASIL}

Hasil penelitian terhadap Ahli Tenis Lapangan dan ahli Penjas terkait dengan kualitas produk permainan Mikro Tenis untuk pembelajaran tenis lapangan, diperoleh deskripsi dari aspek (1) Kesesuaian dengan Capaian Pembelajaran Mata Kuliah (2) kesesuaian produk dengan karakteristik mahasiswa, (3) keaktifan mahasiswa, dan (4) Kelayakan produk permainan MIKRO TENIS. Hasil pengisian penilaian ahli dapat disajikan dalam tabel sebagai berikut :

Tabel 2. Hasil Penilaian Ahli tentang Kesesuaian Produk dengan Capaian Pembelajaran Mata Kuliah

\begin{tabular}{clc}
\hline NO & \multicolumn{1}{c}{ PERIHAL } & $\begin{array}{l}\text { KUALITAS } \\
\text { JAWABAN }\end{array}$ \\
\hline 1 & $\begin{array}{l}\text { Kesesuaian dengan } \\
\text { CPMK materi } \\
\text { permainan tenis } \\
\text { lapangan } \\
\text { Mendorong } \\
\text { perkembangan aspek } \\
\text { kognitif mahasiswa }\end{array}$ & $100 \%$ \\
3 & $\begin{array}{l}\text { Mendorong } \\
\text { perkembangan aspek } \\
\text { afektif mahasiswa } \\
\text { Mendorong } \\
\text { perkembangan aspek } \\
\text { psikomotor mahasiswa } \\
\text { Mendorong } \\
\text { perkembangan aspek } \\
\text { fisik / jasmani } \\
\text { mahasiswa }\end{array}$ & $100 \%$ \\
\hline
\end{tabular}


Tabel analisis data pada lampiran hasil pengisian penilaian ahli tentang kesesuaian produk dengan standar kompetensi, dan kompetensi dasar, dapat disimpulkan bahwa produk permainan ini dapat digunakan.

Tabel 3. Hasil Penilaian Ahli tentang Kesesuaian Produk dengan Karakteristik Mahasiswa

\begin{tabular}{|c|c|c|}
\hline $\begin{array}{c}\text { NO } \\
.\end{array}$ & PERIHAL & $\begin{array}{l}\text { KUALITAS } \\
\text { JAWABAN }\end{array}$ \\
\hline $\begin{array}{l}3 \\
4\end{array}$ & $\begin{array}{l}\text { Kesesuaian bentuk } \\
\text { permainan dengan } \\
\text { karakteristik } \\
\text { mahasiswa } \\
\text { Ketepatan memilih } \\
\text { bentuk permainan bagi } \\
\text { mahasiswa } \\
\text { Dapat dimainkan } \\
\text { mahasiswa terampil } \\
\text { maupun tidak terampil } \\
\text { Dapat dimainkan } \\
\text { mahasiswa putra } \\
\text { maupun putri }\end{array}$ & $100 \%$ \\
\hline $\begin{array}{l}\text { hasi } \\
\text { kese } \\
\text { mah } \\
\text { proc } \\
\text { Tab } \\
\text { Kes } \\
\text { Mal }\end{array}$ & $\begin{array}{l}\text { Tabel analisis data } \\
\text { pengisian penilaian } \\
\text { uaian produk dengan } \\
\text { tsiswa, dapat disimp } \\
\text { ak permainan ini dapat d } \\
\text { 4. Hasil Penilaian } \\
\text { suaian Produk deng } \\
\text { asiswa }\end{array}$ & $\begin{array}{l}\text { unakan. } \\
\text { hli tentan } \\
\text { Keaktifa }\end{array}$ \\
\hline NO & 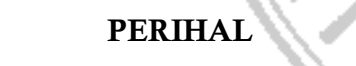 & \\
\hline $\begin{array}{l}1 \\
2\end{array}$ & $\begin{array}{l}\text { Mendorong mahasiswa } \\
\text { aktif bergerak } \\
\text { Meningkatkan minat } \\
\text { dan motivasi mahasiswa } \\
\text { berpartisipasi dalam } \\
\text { pembelajaran permainan } \\
\text { tenis lapangan }\end{array}$ & $\begin{array}{l}100 \% \\
100 \%\end{array}$ \\
\hline
\end{tabular}

Tabel analisis data pada lampiran hasil pengisian penilaian ahli tentang kesesuaian produk dengan keaktifan mahasiswa, dapat disimpulkan berdasarkan kriteria yang telah ditetapkan maka aspek produk permainan Mikro Tenis dapat mendorong mahasiswa aktif bergerak dan meningkatkan minat dan motivasi mahasiswa berpartisipasi dalam pembelajaran permainan tenis lapangan serta kriteria sangat baik sehingga produk permainan ini dapat digunakan.
Tabel 5. Hasil Penilaian Ahli tentang Kelayakan Produk dengan Peraturan Permainan

\begin{tabular}{clc}
\hline NO & \multicolumn{1}{c}{ PERIHAL } & $\begin{array}{c}\text { KUALITAS } \\
\text { JAWABAN }\end{array}$ \\
\hline 1 & $\begin{array}{l}\text { Kejelasan petunjuk } \\
\text { permainan Mikro Tenis }\end{array}$ & $92 \%$ \\
2 & $\begin{array}{l}\text { Kesesuaian alat dan } \\
\text { fasilitas yang digunakan }\end{array}$ & $100 \%$ \\
3 & $\begin{array}{l}\text { Peraturan mudah untuk } \\
\text { dipahami mahasiswa }\end{array}$ & $83 \%$ \\
& $\begin{array}{l}\text { Aman untuk diterapkan } \\
\text { dalam pembelajaran } \\
\text { permainan tenis } \\
\text { lapangan }\end{array}$ & $100 \%$ \\
\hline
\end{tabular}

Tabel analisis data pada lampiran hasil pengisian penilaian ahli tentang kesesuaian produk dengan karakteristik mahasiswa, dapat disimpulkan berdasarkan kriteria yang telah ditetapkan maka produk telah memenuhi kriteria sangat baik sehingga produk permainan ini dapat digunakan.

\section{PEMBAHASAN}

Permainan Mikro Tenis dapat Mengatasi Keterbatasan Sarana dan Prasarana dalam Pembelajaran Permainan Tenis lapangan

Penelitian yang telah dilaksanakan, diperoleh hasil bahwa produk permainan Mikro Tenis dapat mengatasi keterbatasan sarana dan prasarana/dalam pembelajaran permainan tenis lapangan. Hal itu dibuktikan dengan pembelajaran permainan Mikro Tenis dapat dilakukan pada semua kondisi lahan kosong yang ada di kampus seperti lapangan tenis, pavingan, dan aspal.

Bola yang digunakan dalam permainan Mikro Tenis adalah bola tenis lapangan dan bola soft atau bola tonnis. Bola tenis digunakan saat berada di lapangan tenis dan bola soft/tonnis digunakan di lapangan aspal atau pavingan. Sehingga dengan pengunaan bola soft/tonnis ini sangat memungkinkan materi pembelajaran dapat tersampaikan dengan baik kepada mahasiswa pada semua kondisi lapangan/lahan kosong.

Permainan Mikro Tenis dapat menjadi solusi atas keterbatasan lapangan tenis yang ada di kampus, karena seperti kita ketahui penggunaan lapangan yang ada di kampus sangat padat, padahal kebutuhan untuk belajar gerak utamanya gerak teknik dasar pukulan dalam tenis lapangan membutuhkan jumlah lapangan yang 
banyak. Penggunaan bola soft/tonnis dan lapangan permainan Mikro Tenis yang fleksibel terhadap segala bentuk permukaan lapangan, ukuran lapangan, dan jenis lapangan permainan yang digunakan dapat menjadi jalan keluar untuk mengatasi keterbatasan sarana dan prasarana pembelajaran permainan tenis lapangan.

Berdasarkan pembahasan di atas, dapat disimpulkan bahwa permainan Mikro Tenis dapat mengatasi keterbatasan sarana dan prasarana dalam pembelajaran permainan tenis lapangan.

Permainan Mikro Tenis Dapat Meningkatkan Minat Mahasiswa Dalam Mengikuti Proses Pembelajaran Permainan Tenis Lapangan

Minat mahasiswa terhadap permainan Mikro Tenis muncul karena faktor originalitas produk permainan yang baru pertama kali mereka kenal. Secara psikologi, mahasiswa pada usia mahasiswa sangat tertarik akan hal-hal baru dalam aktivitas gerak, dimana dalam hal ini berupa produk permainan Mikro Tenis. Dengan adanya hal baru, maka mahasiswa secara otomatis lebih tertarik untuk melakukan aktivitas gerak yang baru sehingga secara tidak langsung hal tersebut dapat meningkatkan minat mahasiswa dalam mengikuti pembelajaran permainan tenis lapangan melalui akitvitas permainan Mikro Tenis.

\section{Permainan Mikro Tenis dapat} Meningkatkan Intensitas Fisik Mahasiswa dalam Proses Pembelajaran Permainan Tenis lapangan

Peningkatan intensitas fisik dapat diketahui dari pengambilan data dari denyut nadi, dimana selisih antara denyut nadi sebelum pembelajaran dan denyut nadi sesudah pembelajaran dapat menjadi indikator peningkatan intensitas fisik mahasiswa selama proses pembelajaran berlangsung.

Peningkatan denyut nadi sebagai instrument peningkatan intensitas fisik, dipengaruhi oleh beberapa hal yang dapat mempengaruhi peningkatan tersebut, antara lain (1) materi teknik dasar yang heterogen, memungkinkan mahasiswa dapat terus aktif bergerak dalam pembelajaran permainan Mikro Tenis (2) ukuran lapangan yang disesuaikan dengan tingkat pertumbuhan, perkembangan, dan kemampuan fisik mahasiswa akan memudahkan mahasiswa untuk nyaman dalam mengikuti pembelajaran (3) penggunaan bola yang sesuai dengan karakteristik permainan tenis lapangan sehingga membuat mahasiswa termotivasi untuk mengikuti pembelajaran (4) metode pembelajaran permainan Mikro Tenis melalui metode game membuat mahasiswa tidak jenuh dalam mengikuti proses pembelajaran.

Penggunaan produk permainan Mikro Tenis, telah memberikan dampak atau pengaruh terhadap peningkatan denyut nadi mahasiswa sebesar 65,42\%. Disamping itu, hasil penghitungan denyut nadi mahasiswa sesudah pembelajaran mampu mengalami kenaikan sebesar 55\% dari denyut nadi maksimal. Hasil ini juga menunjukkan kesesuaian dengan intensitas latihan yang disarankan yaitu 60 - 80\% dari denyut nadi maksimal. Penggunaan produk pembelajaran tenis mampu menaikkan intensitas denyut nadi sebesar $66,18 \%$ dari denyut nadi maksimal (Avip, 2013)

Peningkatan denyut nadi dapat digunakan sebagai indikator adanya peningkatan intensitas fisik mahasiswa. Intensitas fisik dapat meningkat karena respon denyut nadi akibat adanya aktivitas fisik mahasiswa saat bermain permainan Mikro Tenis. Denyut nadi respon ini dapat menjadi tolak ukur adanya peningkatan denyut nadi mahasiswa dalam mencapai intensitas latihan yang disarankan. Peningkatan rata-rata denyut nadi berupa respon sebesar 65,42 \% terhadap aktivitas yang dilakukan, merupakan salah satu indikator bahwa permainan Mikro Tenis dapat meningkatkan intensitas fisik mahasiswa dalam proses pembelajaran permainan tenis lapangan.

\section{Permainan Mikro Tenis Efektif untuk Proses Pembelajaran Permainan Tenis lapangan}

Hasil studi pendahuluan penelitian yang dilakukan peneliti di beberapa perkuliahan di jurusan PJKR, IKOR dan PKLO diperoleh hasil bahwa alokasi waktu pembelajaran permainan tenis lapangan 2 SKS atau 340 menit (satu kali pertemuan), akan tetapi yang terjadi di lapangan untuk mata kuliah tenis lapangan implementasi di lapangan hanya 100 menit kegiatan perkuliahan efektif dilaksanakan. Sisa 240 menit digunakan untuk kegiatan mandiri, diluar jadwal perkuliahan. Hal ini tentunya menjadi tugas seorang tenaga pengajar untuk mencari solusi alternatif agar proses 
pembelajaran bisa tercapai semua disamping dengan keterbatasan lapangan yang tersedia. Permainan Mikro Tenis juga dapat mengembangkan ketiga ranah pembelajaran (kognitif, afektif, dan psikomotor) yang diharapkan dapat berkembang secara optimal bagi mahasiswa. Ketiga ranah tersebut bisa berkembang melalui pembelajaran permainan Mikro Tenis.

Ranah kognitif mahasiswa dapat berkembang dengan optimal dibuktikan dengan adanya pengetahuan bagi mahasiswa terkait dengan materi teknik dasar permainan tenis lapangan (forehand dan backhand), variasi dan kombinasi permainan tenis lapangan, dan peraturan permainan Mikro Tenis. Pengetahuan tentang pembelajaran permainan Mikro Tenis diharapkan dapat mengembangkan ranah kognitif mahasiswa dalam memahami materi yang disampaikan.

Ranah afektif mahasiswa dapat berkembang dengan optimal dibuktikan dengan adanya penerapan nilai-nilai yang terkandung dalam permainan tenis lapangan baik nilai kerjasama, tanggung jawab, maupun berbagi peralatan dan tempat dalam proses pembelajaran melalui penerapan produk permainan Mikro Tenis dalam pembelajaran permainan tenis lapangan.

Ranah psikomotor mahasiswa dapat berkembang dengan optimal dibuktikan dengan adanya koordinasi gerak kompleks dalam pembelajaran permainan tenis lapangan melalui permainan Mikro Tenis. Koordinasi gerak yang dipraktikkan mahasiswa yaitu koordinasi gerak mata tangan yang diaplikasikan dalam pembelajaran teknik pukulan forehand dan backhand dan koordinasi gerak mata kaki yang diaplikasikan dalam footwork teknik pukulan forehand dan backhand. Modifikasi pembelajaran dengan permainan tonnis memberikan peningkatan hasil belajar pukulan forehand siswa, (Naim dan Wibowo, 2013)

Berdasarkan penjelasan di atas, dapat ditarik kesimpulan bahwa permainan Mikro Tenis dapat menciptakan efektivitas waktu pembelajaran permainan tenis lapangan. Permaian Mikro Tenis juga mengembangkan ketiga ranah pembelajaran baik ranah kognitif, ranah afektif maupun ranah psikomotor yang dibutuhkan mahasiswa.

\section{KESIMPULAN}

Kesimpulan penelitian ini adalah Produk permainan Mikro Tenis cocok digunakan sebagai alternatif pembelajaran permainan tenis lapangan. Penggunaan produk permainan Mikro Tenis dapat mengatasi keterbatasan sarana dan prasarana pembelajaran permainan tenis lapangan. Penggunaan produk permainan Mikro Tenis dapat meningkatkan minat peserta didik dalam proses pembelajaran tenis lapangan, dan. Permainan Mikro Tenis telah memberikan pengaruh terhadap peningkatan denyut nadi mahasiswa

\section{DAFTAR PUSTAKA}

Avip, Ath-Thoriq. (2013). Pengembangan Permainan Tenis Untuk Pembelajaran Pendidikan Jasmani, Olah-Raga Dan Kesehatan Siswa Sekolah Menengah Atas. Journal of Physical Education and Sports, 2(1).

Farida. Lulu. A 2014. Pengembangan Permainan Foot And Hand Coordination Untuk Pembelajaran Pendidikan Jasmani, Olahraga, Dan Kesehatan Siswa Sekolah Dasar. Universitas Negeri Semarang.

Hartono. M 2017. Pengembangan Bola Multifungsi untuk Pembelajaran Pendidikan Jasmani, Olahraga, dan Kesehatan. Program Pascasarjana Universitas Negeri Semarang.

Naim, M. K. A. F., \& Wibowo, S. Modifikasi pembelajaran dengan permainan tonnis terhadap hasil belajar pukulan forehand tenis lapangan. Jurnal Pendidikan Olahraga dan Kesehatan Vol. 01 (02) 2013, 424 - 427

Poerwadarminta, W.J.S. 2005. Kamus Umum Bahasa Indonesia. Edisi Ketiga. Jakarta: Balai Pustaka.

Ricko Irawan. 2016. Model Latihan Drill Dengan Power Lengan Tinggi Dan Rendah Terhadap Hasil Servis Slice Petenis Putra Usia 10-12 Tahun. Universitas Negeri Semarang. 
Siswoyo, Dwi dkk. 2007. Ilmu Pendidikan. Yogyakarta: UNY Press.

Susantoro, A.A. 1990. Sejarah Pers Indonesia. Jakarta.

Nurharsono. T. 2009. Permainan Tonnis. Kementerian Hukum dan Hak Asasi Manusia.

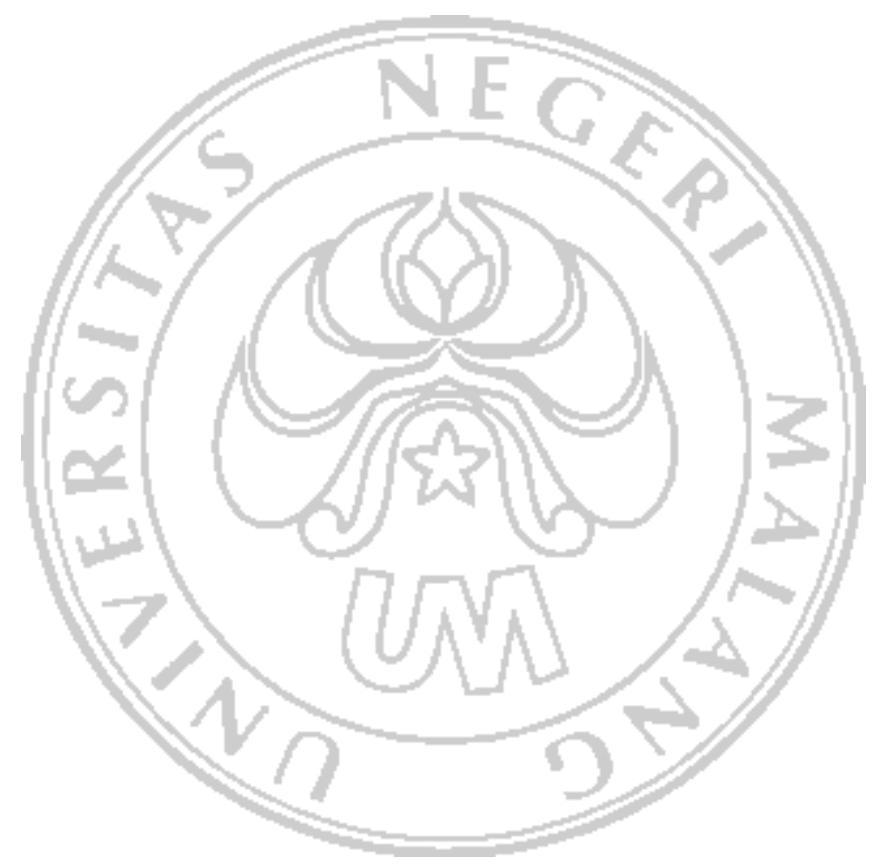

